mise en œuvre d'une soixantaine de projets, en cours ou complétés, dont les résultats méritent une diffusion élargie, notamment dans le contexte de l'adoption des prochains PAFI, prévue pour avril 2013. Ce sont plus de 2 M. \$ qui ont été octroyés à ce jour pour la réalisation des projets. Soulignons que le programme est rendu possible grâce aux revenus générés par la hausse du prix des permis québécois de chasse, de pêche et de piégeage entrée en vigueur le $1^{\mathrm{e}}$ avril 2009. Cette hausse a généré des revenus qui sont réinvestis dans le secteur faunique.

Les présentations faites dans le cadre du colloque sont disponibles sur le site de l'Ordre des ingénieurs forestiers du
Québec à l'adresse : http://www.oifq. com/fr/membres/formation-continue/ formations-passees/colloque-gir-2013/

Pierre Breton, ing.f. Coordonnateur de projets Fondation de la Faune du Québec

\section{Resilience and the Cultural Landscape Understanding and Managing Change in Human-Shaped Environments}

Tobias Plieninger and Claudia Bieling (eds.), 2012. ISBN 978-1-107-02078-8 Cambridge University Press, New York, NY. CAD \$70.95 + shipping. Contact: publicity@cambridge.org

$A^{1}$ 11 over the world, efforts are being made to preserve landscapes facing fundamental change as a consequence of widespread agricultural intensification, land abandonment and urbanization. The "cultural landscape" and "resilience" approaches have, until now, been viewed largely as distinct frameworks for understanding the effects of these dynamics and the ways in which they might be adapted or managed. This book brings together these two perspectives, providing new insights into the social-ecological resilience of cultural landscapes by coming to terms with, and challenging, the concepts of driving forces, thresholds, adaptive cycles and adaptive management.

By linking these research communities, this book develops a new perspective on landscape changes. Based on firm conceptual contributions and rich case studies from Europe, the Americas and Australia, it will appeal to anyone interested in analyzing and managing change in human-shaped environments in the context of sustainability.

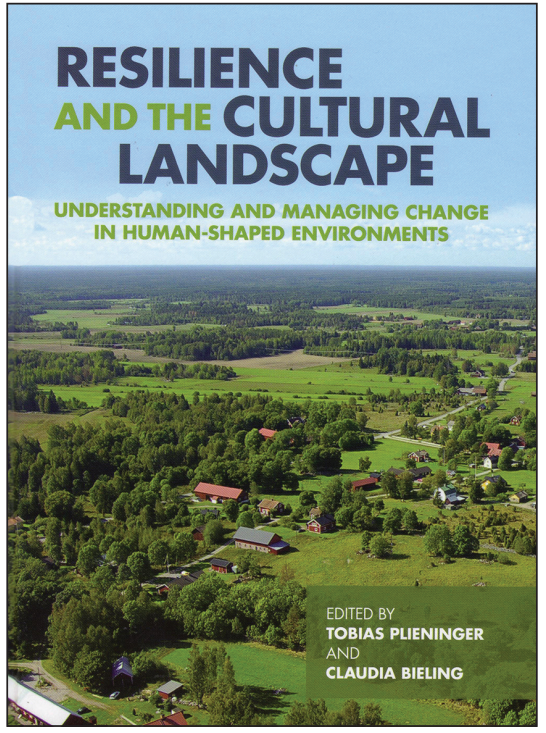

If you purchase a book as the result of a Forestry Chronicle announcement, please mention that you saw it in the Chronicle!

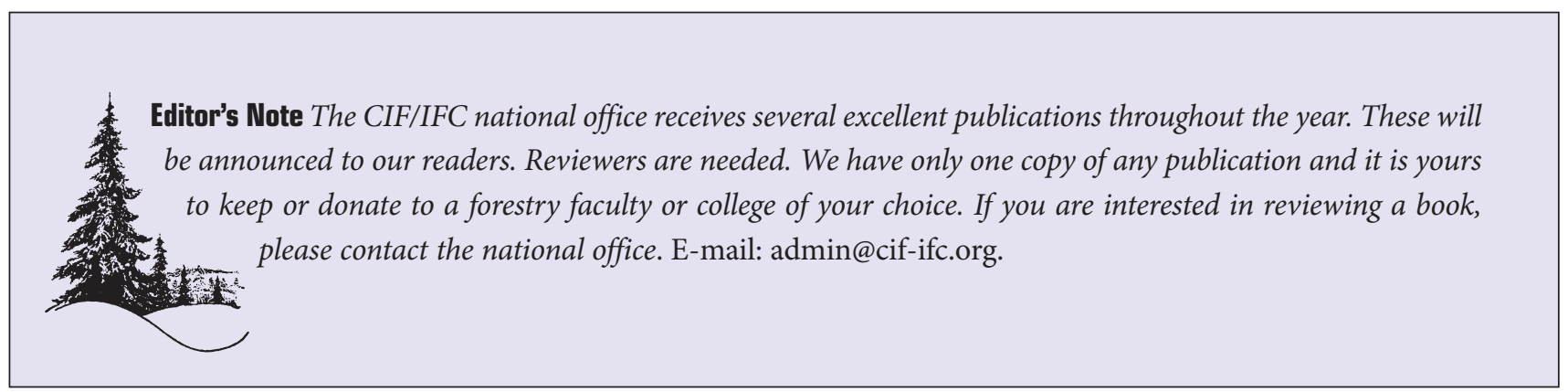

